\title{
Bone of the Upper Extremity
}

National Cancer Institute

\section{Source}

National Cancer Institute. Bone of the Upper Extremity. NCI Thesaurus. Code C12983.

A bone of the arm (upper extremity). 